\title{
Preparation of recombinant Kluyveromyces lactis agents for simultaneous degradation of two mycotoxins
}

\author{
Yu Xia ${ }^{1,2^{*}}$, Yangyu Qiu ${ }^{2}$, Zifeng $\mathrm{Wu}^{2}$, Qianqian Cheng ${ }^{2}$, Xiuyu $\mathrm{Hu}^{3}$, Xiaobing Cui ${ }^{4}$ and Zhouping Wang ${ }^{1,2}$
}

\begin{abstract}
Aflatoxin $B_{1}\left(A F B_{1}\right)$ and zearalenone (ZEN) are widely distributed in corns, peanuts, and other cereals, causing serious threat to food safety and human health. As shown by our previous studies, the recombinant yeast strain Kluyveromyces lactis GG799(pKLAC1-ZPF1) had the ability of degrading AFB 1 and ZEN simultaneously. In this work, the agent preparation process was optimized for K. lactis GG799(pKLAC1-ZPF1), and the storage conditions of the prepared yeast agents were investigated, for obtaining the products with high storage activities and potent mycotoxin degradation efficiency. The optimal preparation process was as follows: centrifugation at $6000 \mathrm{rpm}$ for $15 \mathrm{~min}$ for collection of the yeast cells, spray drying with the ratio of protective compounds to yeast cells at 3:1 (w/W) and then stored at $-20^{\circ} \mathrm{C}$. Simultaneous degradation tests of $\mathrm{AFB}_{1}$ and $\mathrm{ZEN}$ were performed using the supernatants of reactivated yeast agents after three months of storage, and the degradation ratios for $\mathrm{AFB}_{1}$ and $\mathrm{ZEN}$ in reaction system $1(70.0 \mathrm{mmol} / \mathrm{L}$ malonic buffer, $\mathrm{pH} 4.5$, with $1.0 \mathrm{mmol} / \mathrm{L} \mathrm{MnSO}_{4}, 0.1 \mathrm{mmol} / \mathrm{L} \mathrm{H}_{2} \mathrm{O}_{2}, 5.0 \mu \mathrm{g} / \mathrm{mL} \mathrm{AFB}$ and $\mathrm{ZEN}$, respectively) were $48.2 \pm 3.2 \%$ and $34.8 \pm 2.8 \%$, while that for ZEN in reaction system $2(50.0 \mathrm{mmol} / \mathrm{L}$ Tris $-\mathrm{HCl}, \mathrm{pH} 7.5$, with $5.0 \mu \mathrm{g} / \mathrm{mL}$ $A F B_{1}$ and $Z E N$, respectively) was $30.1 \pm 2.7 \%$. Besides, the supernatants of reactivated yeast agents degraded more than $80 \%$ of $A_{F B}$ and $55 \%$ of ZEN in contaminated peanuts after twice treatments. Results of this work suggested that the optimized process for K. lactis GG799(pKLAC1-ZPF1) was with high value for industrial applications.
\end{abstract}

\section{Key points}

- The recombinant strain K. lactis GG799(pKLAC1-ZPF1) was food-grade and safe for food and feed industry.

- The preparation processes of the K. lactis GG799(pKLAC1-ZPF1) agents were optimized, and the storage properties were investigated.

- The culture supernatants of the reactivated yeast agents, rather than the purified enzymes, were used to degrade $\mathrm{AFB}_{1}$ and $\mathrm{ZEN}$ in practical samples for reducing the production cost.

Keywords: Kluyveromyces lactis, Yeast agent preparation, Aflatoxin $\mathrm{B}_{1}$, Zearalenone, Degradation

\footnotetext{
*Correspondence: yuxia@jiangnan.edu.cn

${ }^{1}$ State Key Laboratory of Food Science and Technology, Jiangnan

University, Wuxi 214122, China

Full list of author information is available at the end of the article
}

\section{Introduction}

Mycotoxins are secondary metabolites produced by fungi which could lead to adverse effects after intake by human beings or animals(Ayofemi Olalekan Adeyeye 2020). Aflatoxin $\mathrm{B}_{1}\left(\mathrm{AFB}_{1}\right)$ and zearalenone (ZEN), as two major fungal toxins, are widely distributed in food stuffs such as peanuts, corns, and other grains, causing serious damage 
to human or animal health (Lee and Ryu 2017; Nazhand et al. 2020; Eskola et al. 2020). Currently, the main detoxification methods for mycotoxins include physical, chemical, and biological ones. However, the physical methods including heat treatment, adsorption, separation and irradiation, tend to destroy flavor and nutrients of grains and cannot completely reduce mycotoxins (Wu et al. 2021). Chemical methods involve ozone detoxification, hydrogen peroxide treatment, alkali treatment, sodium carbonate soaking treatment and ammoniation (Rempe et al. 2013). Although chemical methods can alter the structure of mycotoxins and detoxify mycotoxins from contaminated cereals, their usage can also easily cause secondary pollution (Xu et al. 2021). Meanwhile, the high risk and low efficiency limit the application of chemical methods in food industry (Ryu et al. 1999; Loi et al. 2017). Biological methods are effective for degradation of fungal toxins gently and efficiently (Adebo et al. 2017; Wang et al. 2019b). Currently, several enzymes have been identified having the ability for degradation of $\mathrm{AFB}_{1}$ and ZEN respectively, and most of them have been expressed recombinantly in Escherichia coli and yeast systems. Considering the wide range and diversity of mycotoxins worldwide, there is an urgent demand for methods that can detoxify two or more mycotoxins simultaneously. Kluyveromyces lactis has emerged as one of the most prominent yeast species for research, and has been extensively used in food and feed industry for a long time due to their generally regarded as safe (GRAS) status (Spohner et al. 2016; van den Dungen et al. 2021). As a result, the recombinant strain $K$. lactis GG799(pKLAC1ZPF1) was a food-safe strain. In our previous works, we selected zearalenone hydrolase ZHD101.1 (ZHD101 mutant V153H) from Clonostachys rosea and manganese peroxidase PhcMnp from Phanerochaete chrysosporium for construction of the fusion enzyme ZPF1. The enzyme ZHD101.1 specifically hydrolyzes ZEN into a nontoxic alkyl resorcinol product by destroying its lactone bond, while the enzyme PhcMnp oxidizes $\mathrm{AFB}_{1}$ to $\mathrm{AFB}_{1}$-8,9-dihydrodiol due to its high redox potential. Its oxidation is mainly through free radicals, which are produced by interaction of oxidized $\mathrm{Mn}^{3+}$ with dicarboxylic acid malonate. Besides, our previous studies showed that the recombinant yeast strain K. lactis GG799(pKLAC1ZPF1) successfully achieved simultaneous degradation of $\mathrm{AFB}_{1}$ and ZEN (Xia et al. 2021a).

Yeast agents, which have no toxins creation, no harmful and residual effects, are excellent alternatives to antibiotics and have great potentials for application in feed industry (Zhong et al. 2018). Present research on the degradation of mycotoxins was mainly focused on the construction of recombinant strains, the optimization of cultural conditions and degradation reaction parameters
(Jiang et al. 2008; Xiang et al. 2016). To satisfy the industrial production, the research on the preparation of agent using the described $K$. lactis GG799(pKLAC1-ZPF1) became urgently needed. In the process of yeast agents preparation, the centrifugation conditions after cultivation, the kind and the ratio of protective compounds, the drying process and treatment time would have impacts on the activity of the dried powders (Palmfeldt et al. 2003; Wang et al. 2019a). In addition, storage conditions are also important factors that should be taken into consideration for yeast agents preparation, in order to remain the microbial active (Sullivan and Bradford 2011). In general, selecting the appropriate preparation process can keep the viability of the cells at maximum extent, enhancing the expression levels and achieving high degradation efficiency of the mycotoxins. In this short communication, the agent preparation process was optimized for K. lactis GG799(pKLAC1-ZPF1), which provided an effective reference for toxin degradation in the field of grain feed industry and the industrial production of $K$. lactis GG799(pKLAC1-ZPF1) agents.

\section{Meterials and methods}

\section{Strains, cultural conditions and chemicals}

The recombinant strain K. lactis GG799(pKLAC1-ZPF1) (Xia et al. 2021a) were preserved in this laboratory. Recombinant strain was grown at $30^{\circ} \mathrm{C}$ in YEPD medium (yeast extract $1 \%$, peptone $2 \%$, glucose $2 \%$, pH 6.3 ). For induction expression of ZPF1, YEPG medium $(1.0 \%$ yeast extract, $2.0 \%$ peptone, $2.0 \%$ galactose, $0.5 \mathrm{mmol} / \mathrm{L}$ $\mathrm{MnSO}_{4}, 0.5 \mathrm{mmol} / \mathrm{L}$ hemin, $\mathrm{pH} 5.9$ ) was used and the strain was cultivated at $30^{\circ} \mathrm{C}, 200 \mathrm{rpm}$ for $96 \mathrm{~h}$.

$\mathrm{AFB}_{1}$ and ZEN were purchased from Pribolab (Shandong, China). In this research work, these standards were made into a $1.0 \mathrm{mg} / \mathrm{mL}$ stock solution with methanol or acetonitrile solvent and were stored in darkness at $-20{ }^{\circ} \mathrm{C}$. Methanol, formic acid, and acetonitrile were purchased from Tedia (OH, USA). All other reagents and chemicals were of analytical reagent grade.

\section{Preparation of the K. lactis GG799(pKLAC1-ZPF1) agents} The recombinant $K$. lactis GG799(pKLAC1-ZPF1) stored at $-80{ }^{\circ} \mathrm{C}$ was cultivated in the YEPD agar medium at $30{ }^{\circ} \mathrm{C}$ and incubated for 3 to 5 days for activation. Single colony was picked and cultivated in YEPD liquid medium at $30{ }^{\circ} \mathrm{C}, 200 \mathrm{rpm}$ for 18 to $22 \mathrm{~h}$. When the $\mathrm{OD}_{600}$ of the cultures reached 1.0, the seed solution was inoculated in a $5 \mathrm{~L}$ fermenter containing $2.0 \mathrm{~L}$ YEPD medium at $28{ }^{\circ} \mathrm{C}$ and aeration of $1.5 \mathrm{vvm}$ for $35 \mathrm{~h}$. The fermentation process was controlled at $28{ }^{\circ} \mathrm{C}, 100 \%$ oxygen solubility, $\mathrm{pH}$ 5.0. The cultures were centrifuged under different centrifugation conditions to collect the yeast cells. The yeast cells and the composite lyophilized protective 
compounds were mixed in different ratios and resuspended separately to prepare uniform cell suspensions. The suspensions were dried by different processes for preparation of $K$. lactis GG799(pKLAC1-ZPF1) agents (Fig. 1).

\section{Optimization of the K. lactis GG799(pKLAC1-ZPF1) agents process}

The initial viable count of the yeast cells was measured by dilution coating with $50.0 \mathrm{~mL}$ of the culture. For the centrifugation conditions, the yeast cells were collected at 5000 to $7000 \mathrm{rpm}$, and the samples treated with each speed conditions were collected at $10 \mathrm{~min}, 15 \mathrm{~min}$ and $20 \mathrm{~min}$, respectively. The centrifuged yeast cells were resuspended in physiological saline and the optimal centrifugation conditions were characterized by the number of viable yeast cells using the dilution coating method.

Different protective compounds protect the cells by different mechanisms, therefore, the protective compounds will be used in combination rather than singly in the actual production process. Thus, skimmed milk powder and maltose were chosen as the compound lyophilization protectant to provide protection and avoid damage to the cells during drying process (Han et al. 2019). The complex lyophilization protective compounds were mixed with yeast cells in different ratios at 1:1 (w/w), 1:2 (w/w), $1: 3(\mathrm{w} / \mathrm{w})$ and $1: 4(\mathrm{w} / \mathrm{w})$.

The cell suspension was prepared according to the above methods. A part of the obtained suspension was used for spray drying. The conditions for spray drying were as following (Stefanello et al. 2019): inlet air temperature was $135{ }^{\circ} \mathrm{C}$, outlet air temperature was $60{ }^{\circ} \mathrm{C}$, and solids content ranged from 15 to $25 \%$. The other part was pre-frozen at $-80{ }^{\circ} \mathrm{C}$ for $3 \mathrm{~h}$ and then used for vacuum freeze drying. The conditions for vacuum freeze drying were as following (Xia et al. 2021b): temperature of condenser was $-40{ }^{\circ} \mathrm{C}$, degree of vacuum was $10 \mathrm{~Pa}$, and drying time was $24 \mathrm{~h}$. The dried samples were weighed and added to physiological saline, placed in an incubator at $30{ }^{\circ} \mathrm{C}$ for $30 \mathrm{~min}$, and then diluted and coated. The optimal mixing ratio and drying process were determined according to the number of viable yeast cells.

\section{Storage of the K. lactis GG799(pKLAC1-ZPF1) agents and degradation test of $\mathrm{AFB}_{1}$ and ZEN}

The $K$. lactis GG799(pKLAC1-ZPF1) agents were placed in sealed bags and stored at $-20^{\circ} \mathrm{C},-4{ }^{\circ} \mathrm{C}$ and $25^{\circ} \mathrm{C}$, respectively. The appropriate amount of yeast agents was taken every month, and the viable yeast cells were counted by dilution coating after reactivation with $10.0 \mathrm{~mL}$ physiological saline.

The reactivated recombinant yeast was cultivated in YEPG medium containing $0.5 \mathrm{mmol} / \mathrm{L} \mathrm{MnSO}_{4}$ and $0.5 \mathrm{mmol} / \mathrm{L}$ hemin at $30{ }^{\circ} \mathrm{C}$ for about $96 \mathrm{~h}$ at a speed of $200 \mathrm{rpm}$. The fermentation supernatants were collected by centrifugation at $8000 \mathrm{rpm}$ and the protein samples were concentrated with $10.0 \mathrm{kDa}$ ultrafiltration tubes. The degradation tests of $\mathrm{AFB}_{1}$ and $\mathrm{ZEN}$ were performed by the supernatants. Due to the two domains on the fusion enzyme ZPF1 (ZHD101.1 and PhcMnp) had different reaction requirements, the degradation efficiency of ZPF1 on $\mathrm{AFB}_{1}$ and ZEN was tested by two different reaction systems (Xia et al. 2021a). The reaction system 1 contained $70.0 \mathrm{mmol} / \mathrm{L}$ malonic acid buffer $(\mathrm{pH} 4.5)$ with $1.0 \mathrm{mmol} / \mathrm{L} \mathrm{MnSO}_{4}, 0.1 \mathrm{mmol} / \mathrm{L} \mathrm{H}_{2} \mathrm{O}_{2}, 1.0 \mathrm{mg} / \mathrm{mL}$ culture supernatant protein, $5.0 \mu \mathrm{g} / \mathrm{mL} \mathrm{AFB}_{1}$ and $5.0 \mu \mathrm{g} /$ $\mathrm{mL}$ ZEN (Wang et al. 2019b), while the reaction system 2 contained $50.0 \mathrm{mmol} / \mathrm{L}$ Tris- $\mathrm{HCl}(\mathrm{pH} 7.5)$ with $5.0 \mu \mathrm{g} /$ $\mathrm{mL} \mathrm{AFB}_{1}$ and $5.0 \mu \mathrm{g} / \mathrm{mL} \mathrm{ZEN}$ (Xiang et al. 2016).

To degrade the two mycotoxins in reaction system 1 , the solution containing all samples was incubated at $30{ }^{\circ} \mathrm{C}$ for $9 \mathrm{~h}$ and then $3.0 \mathrm{~mL}$ of methanol was added
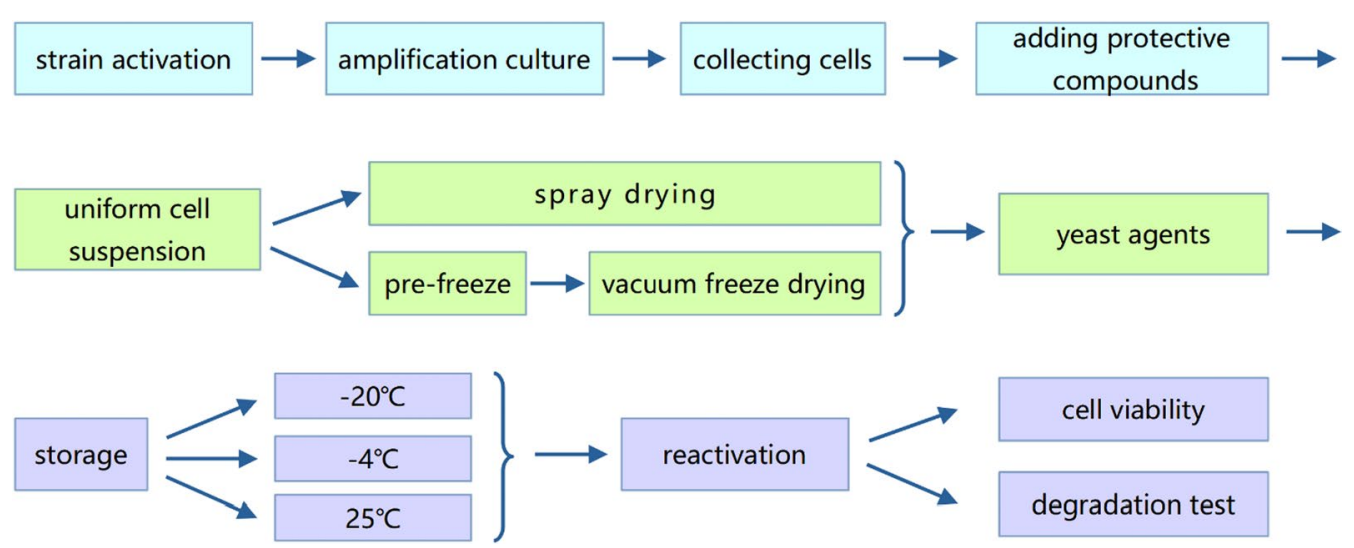

Fig. 1 The process flow-chart for preparation of K. lactis GG799(pKLAC1-ZPF1) agents 
to terminate the reaction (Wang et al. 2019b). To degrade the two mycotoxins in reaction system 2 , the solution containing all samples was incubated at $37^{\circ} \mathrm{C}$ for $30 \mathrm{~min}$ and then $1.0 \mathrm{~mL}$ of methanol was added to terminate the reaction (Xiang et al. 2016) The degradation ratios of ZEN in reaction systems 1 and 2 were denoted as ZEN-1 and ZEN-2, respectively.

\section{Simultaneous degradation of $\mathrm{AFB}_{1}$ and ZEN in contaminated peanut samples}

The peanut samples were shelled to remove the impurities and dust (Yang et al. 2020). The samples were prepared into a powder with a particle size less than $2.0 \mathrm{~mm}$ by a homogenizer. The powder samples $(5.0 \mathrm{~g})$ mixed with $10.0 \mathrm{~mL}$ water were stirred thoroughly, and then autoclaved at $121{ }^{\circ} \mathrm{C}$ for $20 \mathrm{~min}$. The $\mathrm{AFB}_{1}$ standards and ZEN standards were added to the peanut samples at different concentrations respectively $(100.0 \mu \mathrm{g} / \mathrm{kg}, 500.0 \mu \mathrm{g} / \mathrm{kg}, 2000.0 \mu \mathrm{g} / \mathrm{kg})$ and the samples were thoroughly stirred. Then the samples were mixed with the supernatants from the reactivated and cultured yeast agents. The final volume of the reaction system was $35.0 \mathrm{~mL}$ containing $70.0 \mathrm{mmol} / \mathrm{L}$ malonic acid buffer ( $\mathrm{pH} 4.5)$ with $1.0 \mathrm{mmol} / \mathrm{L} \mathrm{MnSO}_{4}$, $0.1 \mathrm{mmol} / \mathrm{L} \mathrm{H}_{2} \mathrm{O}_{2}, 1.0 \mathrm{mg} / \mathrm{mL}$ culture supernatant protein. The concentration of $\mathrm{AFB}_{1}$ and $\mathrm{ZEN}$ was described above. The reaction was performed at $37^{\circ} \mathrm{C}$ for $40 \mathrm{~h}$. After the first degradation treatment, the liquid phase and the solid phase in the samples were separated, and the same volume of the supernatants were added to these solid phase samples again, for the twice treatments of the mycotoxins with the methods described above. The samples were analyzed by UPLCMS for detection of the residual concentration of $A_{F} B_{1}$ and ZEN.

\section{Quantitative assay of $\mathrm{AFB}_{1}$ and ZEN}

The residual degradation samples containing the mycotoxins were filtered through a $0.22 \mu \mathrm{m}$ filter and the residual concentrations of $\mathrm{AFB}_{1}$ and $\mathrm{ZEN}$ were detected by UPLC-MS. The specific operating parameters were as following: chromatographic was performed using ACQUITY UPLC ${ }^{\circledR}$ BEH C18 $(2.1 \times 50$ mm, $1.7 \mu \mathrm{m}$ particle size); the mobile phase was acetonitrile/ water/ formic acid; column temperature was $40{ }^{\circ} \mathrm{C}$; flow rate was $0.3 \mathrm{~mL} / \mathrm{min}$. Mass spectrometry parameters were as following: electrospray ion source; multiple reaction monitoring modes (MRM); heating gas temperature was $500{ }^{\circ} \mathrm{C}$; cone Voltage was $3.0 \mathrm{kV}$; ion source temperature was $150{ }^{\circ} \mathrm{C}$; desolventizing gas rate was 800 L/h (Xia et al. 2021a).

\section{Results}

Effects of centrifugal conditions on the cell viability of the recombinant strain

Centrifugation is a common process of collecting cells, while the speed and time of centrifugation affect the harvest rate and viability of cells. Appropriate centrifugation conditions can improve the results. As shown in Fig. 2, the number of viable yeast cells varied greatly under different centrifugation conditions. At the same speed, the number of viable yeast cells showed a trend of increasing at first and then decreasing with the increase of time. When the centrifugation time was $15 \mathrm{~min}$ and the speed was $6000 \mathrm{rpm}$, the number of viable yeast cells reached up to $2.75 \times 10^{8} \mathrm{CFU} / \mathrm{mL}$. While the centrifugal speed was $7000 \mathrm{rpm}$, the number of viable yeast cells was at low levels. Consequently, the optimal centrifugation condition was $6000 \mathrm{rpm}$ for $15 \mathrm{~min}$.

\section{Optimization of protective compounds components and drying processes}

In this work, for improving the activity of the yeast agents, the drying process of the agents was optimized. According to the above method, the $K$. lactis GG799(pKLAC1-ZPF1) agents were prepared by vacuum freeze drying and spray drying, respectively. As shown in Fig. 3, the protective compounds had significant effects on the viability of the yeast cells. When the ratio of protective compounds to yeast cells was $2: 1(\mathrm{w} / \mathrm{w})$, the viability of the yeast cells was higher in vacuum freeze drying; while the ratio of protective compounds to yeast cells was $3: 1(\mathrm{w} / \mathrm{w})$, the protective effect of spray drying was the best. Considering the production efficiency and the costs, the subsequent study was conducted using spray drying process, with a ratio of $3: 1(\mathrm{w} / \mathrm{w})$ of the protective compounds to yeast cells.

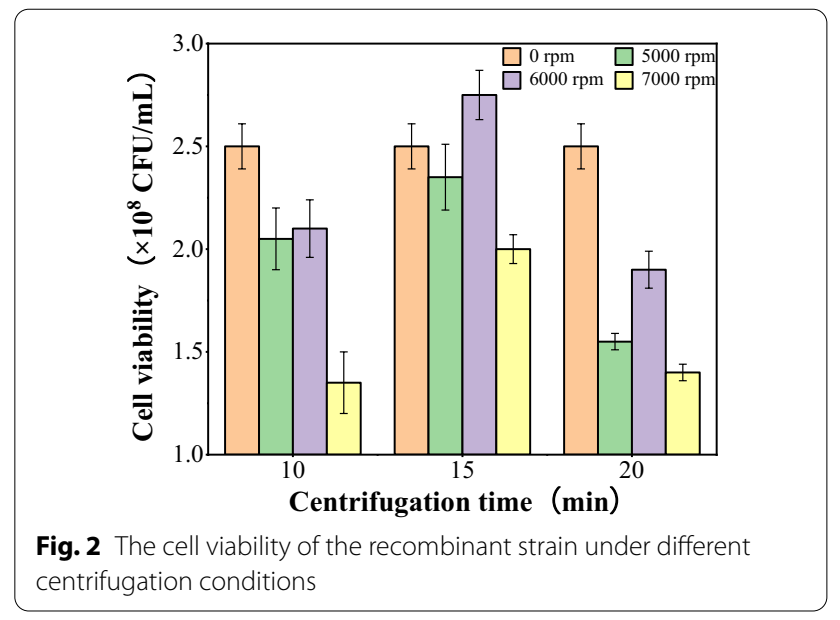



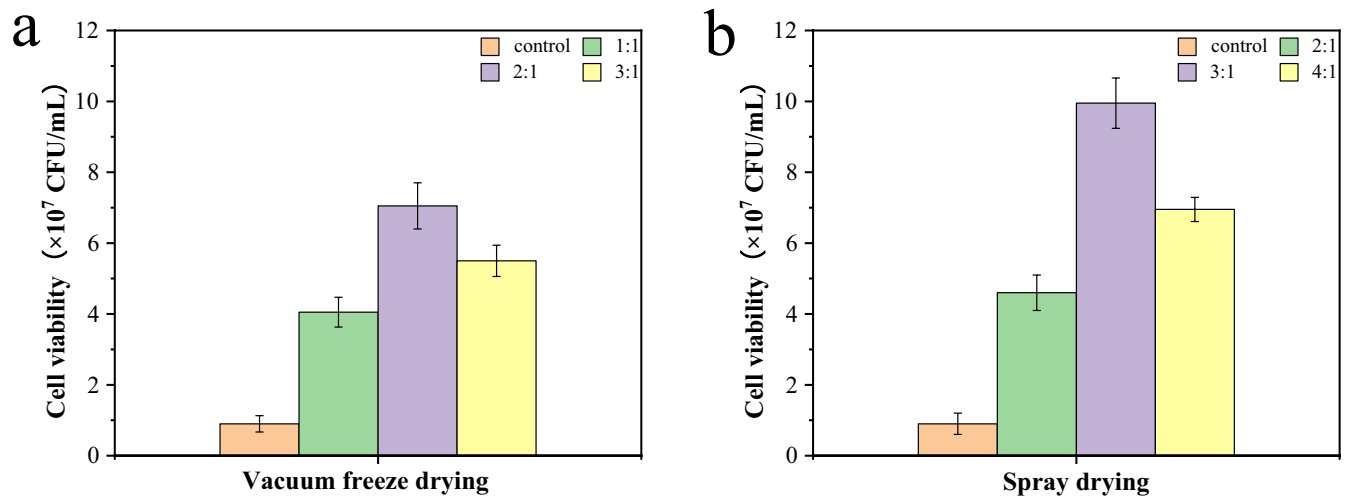

Fig. 3 Effects of different ratios of protective compounds to yeast cells and drying process on K. lactis GG799(pKLAC1-ZPF1) agents. a was the cell viability of the agents obtained by vacuum freeze drying with the different ratios of protective compounds to yeast cells. $\mathbf{b}$ was the cell viability of the agents obtained by spray drying with the different ratios of protective compounds to yeast cells
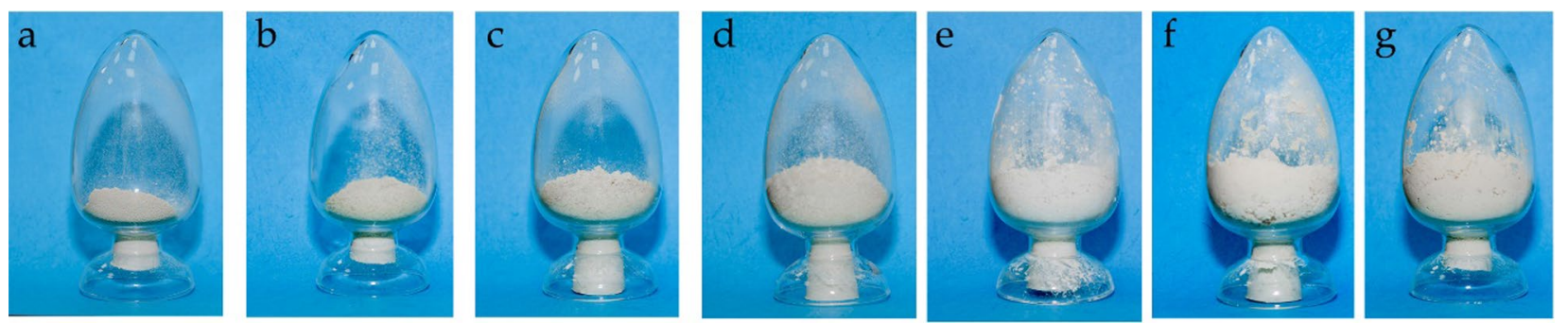

Fig. 4 Products of K. lactis GG799(pKLAC1-ZPF1) agents with different ratios of protective compounds to yeast cells and different drying process. a agents without protective compounds by freeze drying (control); $\mathbf{b}$ agents prepared by freeze drying with protective compounds: yeast cells ratio at 1:1 (w/w); c agents prepared by freeze drying with protective compounds: yeast cells ratio at 2:1 (w/w); d agents prepared by freeze drying with protective compounds: yeast cells ratio at 3:1 (w/w); e agents prepared by spray drying with protective compounds: yeast cells ratio at 2:1; f agents prepared by spray drying with protective compounds: yeast cells ratio at 3:1; $\mathbf{g}$ agents prepared by spray drying with protective compounds: yeast cells ratio at $4: 1$

However, the yeast agents powders obtained by different drying processes showed different properties. The yeast agents powders obtained by spray drying were easy to be lumped, and the humidity and viscosity were larger, compared to the powders obtained by vacuum freeze drying (Fig. 4). Meanwhile, the addition of protective compounds also influenced the properties of the agents. The particle size and viscosity of the agents obtained with addition of protective compounds were lager than the agents obtained without addition of protective compounds.

\section{Cell viability after preservation}

The $K$. lactis GG799(pKLAC1-ZPF1) agents obtained by spray drying with the ratio of protective compounds to yeast cells at $3: 1(\mathrm{w} / \mathrm{w})$ were placed at $-20{ }^{\circ} \mathrm{C},-4{ }^{\circ} \mathrm{C}$ and $25{ }^{\circ} \mathrm{C}$, respectively. The viability of the yeast cells during storage was measured periodically. As shown in Fig. 5, the amount of active yeast in the $K$. lactis GG799(pKLAC1-ZPF1) agents gradually decreased with

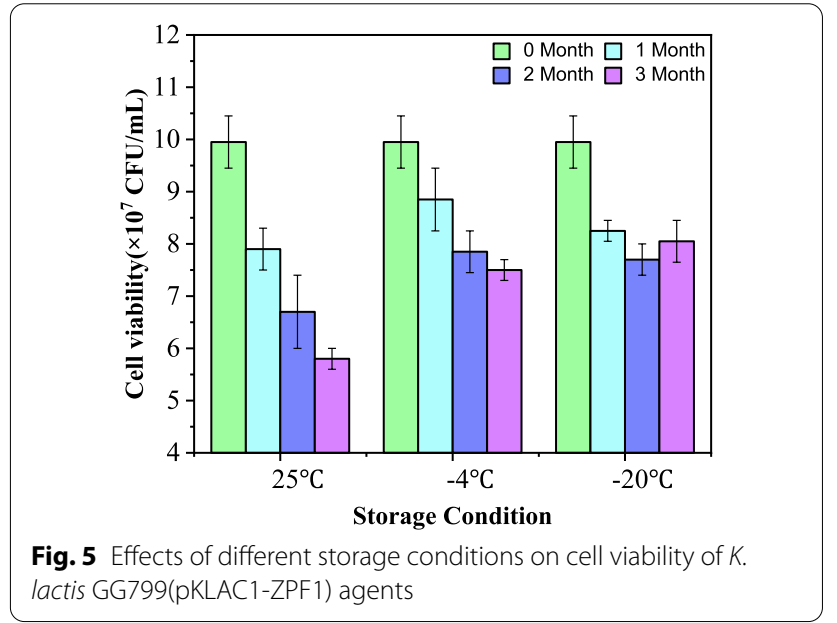

the storage time increased. The activity of yeast cells at $-20{ }^{\circ} \mathrm{C}$ was better than at $-4{ }^{\circ} \mathrm{C}$ and $25{ }^{\circ} \mathrm{C}$. Meanwhile, the $K$. lactis GG799(pKLAC1-ZPF1) agents exhibited 
storage performance at $-20{ }^{\circ} \mathrm{C}$ and kept about $80.9 \%$ cell viability. As a result, the storage at $-20{ }^{\circ} \mathrm{C}$ is more favorable to maintain the activity and physiological status of the recombinant yeast agents.

\section{K. lactis GG799(pKLAC1-ZPF1) agents reactivation and mycotoxins degradation test}

The obtained $K$. lactis GG799(pKLAC1-ZPF1) agents were reactivated, and the fermentation supernatants were used to degrade $\mathrm{AFB}_{1}$ and $\mathrm{ZEN}$. The degradation results of $A_{F B}$ and ZEN were shown in Fig. 6. It can be found that the yeast fermentation supernatants still exhibited degradation effect on $\mathrm{AFB}_{1}$ and $\mathrm{ZEN}$ after the reactivation, but the degradation ratios gradually decreased with the extension of storage time. After three months of storage, the degradation ratios were $48.2 \pm 3.2 \%$ and $34.8 \pm 2.8 \%$ for $\mathrm{AFB}_{1}$ and $\mathrm{ZEN}$, respectively in reaction system 1; and $30.1 \pm 2.7 \%$ for ZEN in reaction system 2 . In system 2, the enzyme ZPF1 in the supernatants had no degradation effect on $\mathrm{AFB}_{1}$, due to the lack of malonic acid and $\mathrm{H}_{2} \mathrm{O}_{2}$.

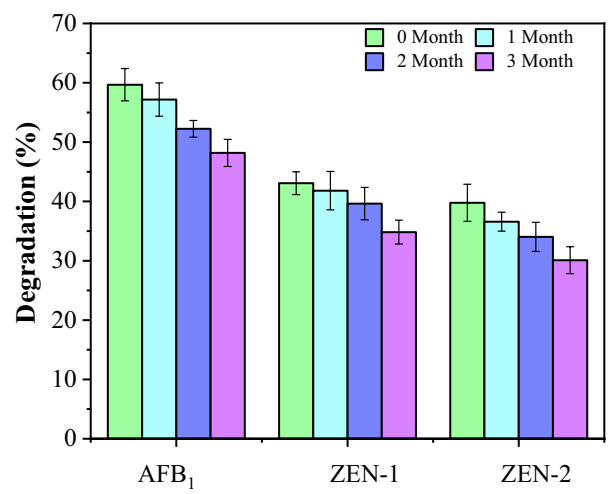

Fig. 6 Degradation ratios of AFB1 and ZEN by the supernatants of reactivated yeast agents
To investigate the degradation effect of the fermentation supernatants on the real samples, degradation tests were performed on peanuts contaminated with $\mathrm{AFB}_{1}$ and ZEN. The degradation results were shown in Table 1 . The supernatants of reactivated yeast agents degraded more than $80 \%$ of $\mathrm{AFB}_{1}$ and $55 \%$ of $\mathrm{ZEN}$ in the contaminated peanuts after twice treatments, with no significant differences $(p>0.05)$, which indicated that the recombinant strain K. lactis GG799(pKLAC1-ZPF1) was suitable for the degradation of $\mathrm{AFB}_{1}$ and $\mathrm{ZEN}$ in feed industry.

\section{Discussion}

The cell viability of the K.lacis GG799(pKLAC1-ZPF1) agents during perparation process is mainly influenced by factors such as centrifugation conditions, protective compounds and drying processes.The number of viable yeast cells varies greatly under different centrifugation conditions. This was due to the fact that low speed reduced the number of viable yeast cells in the supernatants, while the shear force generated at high speed caused damage to the cells and lead to the death of the cells.

During the preparation of the $K$. lactis GG799(pKLAC1-ZPF1) agents, the ratio of protective compounds to yeast cells and the drying process had an impact on the viability of the yeast cells. When the dose of protective compounds was too little, the cells were exposed in large quantities during drying processing, which caused death of the cells and could not play the effective protective role; while the dose of protective compounds was too much, it affected the permeability of the cells, which resulted in the reduction in the viability of the yeast cells. Both of the parameters affect the viability of yeast cells (Palmfeldt et al. 2003).

There are many kinds of common protective compounds, involving sugars, proteins, polyhydroxy compounds, amino acids, etc. Meanwhile, the appropriate protective compounds and ratios vary from strain to strain. The protective compounds can not only avoid

Table 1 Simultaneous degradation results of $A F B_{1}$ and ZEN in contaminated peanuts by the supernatants of reactivated yeast agents

\begin{tabular}{|c|c|c|c|c|c|c|}
\hline Mycotoxins & $\begin{array}{l}\text { Mycotoxin } \\
\text { concentration in } \\
\text { samples } \\
(\mu \mathrm{g} / \mathrm{kg})\end{array}$ & $\begin{array}{l}\text { Mycotoxin } \\
\text { concentration } \\
\text { detected in samples } \\
(\mu \mathrm{g} / \mathrm{kg})\end{array}$ & $\begin{array}{l}\text { Mycotoxin } \\
\text { concentration after } \\
\text { once treatment } \\
(\mu \mathrm{g} / \mathrm{kg})\end{array}$ & $\begin{array}{l}\text { Degradation } \\
\text { ratio after once } \\
\text { treatment (\%) }\end{array}$ & $\begin{array}{l}\text { Mycotoxin } \\
\text { concentration after } \\
\text { twice treatments } \\
(\mu \mathrm{g} / \mathrm{kg})\end{array}$ & $\begin{array}{l}\text { Degradation } \\
\text { ratio after twice } \\
\text { treatments (\%) }\end{array}$ \\
\hline $\mathrm{AFB}_{1}$ & $\begin{array}{l}100.0 \\
500.0 \\
2000.0\end{array}$ & $\begin{array}{l}94.7 \\
436.8 \\
1785.4\end{array}$ & $\begin{array}{l}54.7 \\
243.7 \\
957.0\end{array}$ & $\begin{array}{l}42.2 \pm 4.0 \\
44.2 \pm 1.6 \\
46.4 \pm 2.3\end{array}$ & $\begin{array}{l}12.8 \\
73.4 \\
337.4\end{array}$ & $\begin{array}{l}86.5 \pm 0.9 \\
83.2 \pm 2.3 \\
81.1 \pm 3.7\end{array}$ \\
\hline ZEN & $\begin{array}{l}100.0 \\
500.0 \\
2000.0\end{array}$ & $\begin{array}{l}96.2 \\
476.7 \\
1865.3\end{array}$ & $\begin{array}{l}66.2 \\
337.0 \\
1330.0\end{array}$ & $\begin{array}{l}31.2 \pm 0.8 \\
29.3 \pm 3.6 \\
28.7 \pm 2.7\end{array}$ & $\begin{array}{l}38.0 \\
201.2 \\
833.8\end{array}$ & $\begin{array}{l}60.5 \pm 1.4 \\
57.8 \pm 3.1 \\
55.3 \pm 2.4\end{array}$ \\
\hline
\end{tabular}

Three parallel reactions were done for each group, and the standard deviations were listed 
damage to the cells during drying processing, but also act as a support material during reversion and play a protective role (Coutinho et al. 1988; Berny and Hennebert 1991).

Vacuum freeze drying and spray drying appear to be convenient techniques for the dehydration. The former technology was commonly used as an effective process to produce active dry yeast. The powder obtained by vacuum freeze drying technology had the advantage of high viability and stability, easy for transportation and preservation, but the yield was low, and the production cost is relatively high (Stefanello et al. 2019). The spray drying technology was applicable for mass production; however, the inlet temperature would affect the viability of the yeast cells (Zhou et al. 2017). It is notable that the temperature during spray drying would greatly affect the property of the products. Too high temperature would inactivate the cells, while too low temperature was not beneficial to form the dried powder. Therefore, the import and export temperatures in spray drying processes need to be controlled in practical.

Active yeast agents should be stored at cool temperature and used as quickly as possible if yeast cell viability is to be maintained. As the cryopreservation conditions reduced the moisture content and oxygen pressure in the cells, resulting in slowing down the metabolism of the cells, leaving the cells in semidormancy or dormancy with the anti-aging effects. Even though the $K$. lactis GG799(pKLAC1-ZPF1) agents retained degradation efficiency after the reactivation, the long storage time decreased the activity of the agents, which affected the degradation effects of the fusion enzyme. Meanwhile, the possibility of practical application of this supernatants in the future food industry was verified.

In summary, the preparation process of the $K$. lactis GG799(pKLAC1-ZPF1) agents were developed and optimized. We investigated the viability of yeast cells for characterization of the effects on preparation processes for the K. lactis GG799(pKLAC1-ZPF1) agents. Based on the data obtained, the number of viable yeast cells varies greatly under different preparation conditions. It is obvious that optimal preparation process retains the maximum number of viable cells and reduces inactivity rate. Notably, the K. lactis GG799(pKLAC1-ZPF1) agents still showed excellent ability to degrade $\mathrm{AFB}_{1}$ and ZEN after 3 months of storage at $-20{ }^{\circ} \mathrm{C}$ and the supernatants of reactivated yeast agents were suitable for degradation of $\mathrm{AFB}_{1}$ and $\mathrm{ZEN}$ in practical samples. In addition, this work used the food-safe host $K$. lactis GG799 and the vector pKLAC1, so the fusion enzyme ZPF1 was secretory expressed in a food-grade manner, which property has advantages for applications in food or feed industries the future.

\section{Acknowledgements}

We thank the Jiangsu Agriculture Science and Technology Innovation Fund and the National Natural Science Foundation of China for supporting the research of this work.

\section{Authors' contributions}

YX conceived, designed the research, and prepared the manuscript. YQ, ZW and QC wrote the original draft. YQ, XH and XC wrote, reviewed, and edited the manuscript. $X C$ provided the material resources. $Y X$ and $Z W$ did the project administration and funding acquisition. All authors read and approved the manuscript.

\section{Funding}

This work was financially supported by the Jiangsu Agriculture Science and Technology Innovation Fund (JASTIF) with the No.: CX(19)3109, and the National Natural Science Foundation of China (31871881)

\section{Data availability}

Not applicable.

\section{Declarations}

\section{Ethics approval and consent to participate}

This article does not contain any studies with human participants or animals performed by any of the authors.

\section{Consent for publication}

The manuscript is approved by all authors for publication.

\section{Competing interests}

The authors declare that they have no conflict of interest.

\section{Author details}

${ }^{1}$ State Key Laboratory of Food Science and Technology, Jiangnan University, Wuxi 214122, China. ${ }^{2}$ School of Food Science and Technology, Jiangnan University, Wuxi 214122, China. ${ }^{3}$ China Biotech Fermentation Industry Association, Beijing 100 833, China. ${ }^{4}$ Anhui Heiwa Food-Jiangnan University Joint R\&D Center, Anhui Heiwa Food Technology Co. LTD, Bozhou 233600, China.

Received: 15 December 2021 Accepted: 3 February 2022

Published online: 18 February 2022

\section{References}

Adebo OA, Njobeh PB, Gbashi S, Nwinyi OC, Mavumengwana V (2017) Review on microbial degradation of aflatoxins. Crit Rev Food Sci Nutr 57:32083217. https://doi.org/10.1080/10408398.2015.1106440

Ayofemi Olalekan Adeyeye S (2020) Aflatoxigenic fungi and mycotoxins in food: a review. Crit Rev Food Sci Nutr 60:709-721. https://doi.org/10. 1080/10408398.2018.1548429

Berny J, Hennebert G (1991) Viability and stability of yeast-cells and filamentous fungus spores during freeze-drying-effects of protectants and cooling rates. Mycologia 83:805-815. https://doi.org/10.2307/3760439

Coutinho C, Bernardes E, Félix D, Panek AD (1988) Trehalose as cryoprotectant for preservation of yeast strains. J Biotechnol 7:23-32. https://doi.org/10. 1016/0168-1656(88)90032-6

Eskola M, Kos G, Elliott CT, Hajšlová J, Mayar S, Krska R (2020) Worldwide contamination of food-crops with mycotoxins: validity of the widely cited 'FAO estimate' of 25\%. Crit Rev Food Sci Nutr 60:2773-2789. https://doi. org/10.1080/10408398.2019.1658570

Han C, Liu QG, Liu C, Zhang H, Jiang LZ, Cheng JJ (2019) Selection of freezedrying protective agent of nattokinase from black soybean. J Chin Inst Food Sci Technol 19:112-118. https://doi.org/10.16429/j.1009-7848.2019. 08.013

Jiang F, Kongsaeree P, Schilke K, Lajoie C, Kelly C (2008) Effects of pH and temperature on recombinant manganese peroxidase production and stability. Appl Biochem Biotechnol 146:15-27. https://doi.org/10.1007/ s12010-007-8039-5 
Lee HJ, Ryu D (2017) Worldwide occurrence of mycotoxins in cereals and cereal-derived food products: public health perspectives of their cooccurrence. J Agric Food Chem 65:7034-7051. https://doi.org/10.1021/ acs.jafc.6b04847

Loi M, Fanelli F, Liuzzi V, Logrieco A, Mulè G (2017) Mycotoxin biotransformation by native and commercial enzymes: present and future perspectives. Toxins 9:111. https://doi.org/10.3390/toxins9040111

Nazhand A, Durazzo A, Lucarini M, Souto EB, Santini A (2020) Characteristics, occurrence, detection and detoxification of aflatoxins in foods and feeds. Foods 9:644. https://doi.org/10.3390/foods9050644

Palmfeldt J, Rådström P, Hahn-Hägerdal B (2003) Optimisation of initial cell concentration enhances freeze-drying tolerance of Pseudomonas Chlororaphis. Cryobiology 47:21-29. https://doi.org/10.1016/S0011-2240(03) 00065-8

Rempe I, Brezina U, Kersten S, Dänicke S (2013) Effects of a Fusarium toxin-contaminated maize treated with sodium metabisulphite, methylamine and calcium hydroxide in diets for female piglets. Arch Anim Nutr 67:314-329. https://doi.org/10.1080/1745039X.2013.818762

Ryu D, Hanna MA, Bullerman LB (1999) Stability of Zearalenone during extrusion of corn gritst. J Food Protect 62:1482-1484. https://doi.org/10.4315/ 0362-028X-62.12.1482

Spohner SC, Schaum V, Quitmann H, Czermak P (2016) Kluyveromyces lactis: an emerging tool in biotechnology. J Biotechnol 222:104-116. https://doi. org/10.1016/j.jbiotec.2016.02.023

Stefanello RF, Nabeshima EH, lamanaka BT, Ludwig A, Fries LLM, Bernardi AO, Copetti MV (2019) Survival and stability of Lactobacillus Fermentum and Wickerhamomyces Anomalus strains upon lyophilisation with different cryoprotectant agents. Food Res Int 115:90-94. https://doi.org/10.1016/j. foodres.2018.07.044

Sullivan ML, Bradford BJ (2011) Viable cell yield from active dry yeast products and effects of storage temperature and diluent on yeast cell viability. J Dairy Sci 94:526-531. https://doi.org/10.3168/jds.2010-3553

Van den Dungen MW, Boer R, Wilms LC, Efimova Y, Abbas HE (2021) The safety of a Kluyveromyces lactis strain lineage for enzyme production. Regul Toxicol Pharmacol 126:105027. https://doi.org/10.1016/j.yrtph.2021.105027

Wang XL, Qin X, Hao ZZ, Luo HY, Yao B, Su XY (2019b) Degradation of four major mycotoxins by eight manganese peroxidases in presence of a dicarboxylic acid. Toxins 11:566. https://doi.org/10.3390/toxins11100566

Wang XB, Feng X, Zhang BB, Liu Y, Chen QM, Li F, Zhu Y, Zhang LL (2019a) Study on the freeze-drying microbial agent preparation of an aromaproducing yeast. Food Ferment Sci Technol 55:9-12. https://kns.cnki.net/ kcms/detail/detail.aspx?FileName $=$ SKSF2019a06002\&DbName $=$ CJFQ2 019a

Wu N, Ou W, Zhang ZD, Wang YW, Xu Q, Huang H (2021) Recent advances in detoxification strategies for zearalenone contamination in food and feed. Chin J Chem Eng 30:168-177. https://doi.org/10.1016/j.cjche.2020.11.011

Xia Y, Wu ZF, He R, Gao YH, Qiu YY, Cheng QQ, Ma XY, Wang ZP (2021a) Simultaneous degradation of two mycotoxins enabled by a fusion enzyme in food-grade recombinant Kluyveromyces lactis. Bioresour Bioprocess 8:62. https://doi.org/10.1186/s40643-021-00395-1

Xia Y, Wu ZF, Hu XY, Bao HD, He R, Qiu YY, Cheng QQ, Wang ZP (2021 b) Optimal cultivation conditions for food-grade recombinant yeast that simultaneously degrades two mycotoxins. Food Ferment Ind 47(21):86-93. https:// doi.org/10.13995/j.cnki.11-1802/ts.028751

Xiang L, Wang QH, Zhou YL, Yin LF, Zhang GM, Ma YH (2016) High-level expression of a ZEN-detoxifying gene by codon optimization and biobrick in Pichia Pastoris. Microbiol Res 193:48-56. https://doi.org/10.1016/j.micres. 2016.09.004

Xu HW, Wang LZ, Sun JD, Wang LP, Guo HY, Ye YL, Sun XL (2021) Microbial detoxification of mycotoxins in food and feed. Crit Rev Food Sci Nutr. https://doi.org/10.1080/10408398.2021.1879730

Yang BL, Zhang CX, Zhang XJ, Wang G, Li L, Geng HR, Liu Y, Nie CG (2020) Survey of aflatoxin $B 1$ and heavy metal contamination in peanut and peanut soil in China during 2017-2018. Food Control 118:107372. https:// doi.org/10.1016/j.foodcont.2020.107372

Zhong WG, Qi HW, Yan XG, Yu W, Wei BD, Wu XL (2018) Yeast preparation: application in regulating development of rumen and immunity of calves. Chin J Anim Nutr 30:2085-2089. https://doi.org/10.3969/j.issn.1006-267x. 2018.06.010

Zhou YN, Wang YQ, Liu H, Liu W, Quan ZG, Wang XH, Kou F, Li ZJ, Yang HZ (2017) Study on preparation of Zygosaccharomyces rouxii fermentation agent by spray drying. Food Res Dev 38:114-118. https://doi.org/10. 3969/j.issn.1005-6521.2017.12.025

\section{Publisher's Note}

Springer Nature remains neutral with regard to jurisdictional claims in published maps and institutional affiliations.

\section{Submit your manuscript to a SpringerOpen ${ }^{\circ}$ journal and benefit from:}

- Convenient online submission

- Rigorous peer review

- Open access: articles freely available online

- High visibility within the field

- Retaining the copyright to your article

Submit your next manuscript at $\boldsymbol{\nabla}$ springeropen.com 